\title{
PRICE ADJUSTMENT LAGS AND THEIR ASYMMETRIES IN VIETNAM
}

\author{
Anh The Pham \\ National Economics University, 207 Giai Phong Road, Hanoi, Vietnam \\ Email: pham.theanh@neu.edu.vn \\ Hoang Huy Nguyen \\ Baltimore University, 1420 N. Charles St. Baltimore, MD 21201, US \\ Email: hnguyen@ubalt.edu \\ Hung Duc Nguyen \\ National Economics University, 207 Giai Phong Road, Hanoi, Vietnam \\ Email: nguyenduchung.neu@gmail.com
}

\begin{abstract}
The paper aims to investigate factors that influence the speed of price adjustment in response to shocks by Vietnamese firms using a multivariate ordered probit model with survey data. The results first indicate that whether state or time-dependent price reviewing causes firms to adjust their prices faster after shocks may depend critically on not only the size of shocks but also the economic conditions. Second, we provide evidence that firms used the rule of thumb in price setting tend to adjust their prices more slowly in response to all kind of shocks than their counterparts who based on the market conditions, and that firms whose prices are influenced by competitors tend to be more flexible in reaction to shocks. In addition, we find that menu costs and contracts are the two most important theories in explaining price stickiness. However, they seem to induce firms to respond more slowly only to shocks that drive prices downwards, rather than to shocks that move prices upwards. Finally, the degree of competition, the market share, the size of firms, the practice of quantity discounts, the share of state ownership, and the sector where firms operate all matter for how quickly and asymmetrically firms react to shocks.
\end{abstract}

Keywords: Price adjustment; survey data; multivariate ordered probit;

JEL codes: D40; E31

\section{Introduction}

The micro-based approach which based on survey data has recently become more popular and considered an important complementary method to aggregate time series analysis in investigating the price setting behavior of firms. Amirault, Kwan, and Wilkinson (2005) argued 
that rigid prices can best be understood at the micro level where pricing decisions are made. This is important as many of the modern dynamic stochastic general equilibrium (DSGE) models assume some constraints on price adjustment, often called nominal rigidities, to analyze the effects of monetary policy on the economy.

Studies assessing the empirical validity of nominal rigidities at micro level are rather limited. Blinder (1991, 1994) and Blinder et al. (1998) can be seen as pioneerers and followed by a number papers including Hall, Walsh and Yates (2000), Nakagawa, Hattori and Takagawa (2000), Apel, Friberg and Hallsten (2005), Amirault, Kwan and Wilkinson (2005), Fabiani et al. (2006), Munnik and Xu (2007), Álvarez, Burriel and Hernando (2010), Park, Rayner and D’Arcy (2010), Greenslade and Parker (2012) and Dias et al. (2015). However, most of the papers in the literature focus on investigating the determinants of the frequency of price changes while very few of them concentrate on exploring the underlying factors that influence the speed and magnitude of price adjustments, except for Álvarez and Hernando (2005), Fabiani et al. (2006) and Dias et al. (2015). The results vary substantially depending on not only methods utilized (simple statistic description or complicated regression techniques) but also the sample of countries studied.

As pointed out by Blinder (1991) and Dias et al. (2015), the frequency of price changes is not the best variable to use in empirical studies on the nature and origins of price rigidity since it is likely to depend remarkably on the frequency and magnitude of shocks that hit the firms in the period under consideration. Therefore, examining the determinants of the speed of price responses to demand and cost shocks is meaningful and can be considered an important complemetary in order to enhance our knowledge of price rigidity at firm level. In this paper, we attempt to investigate the underlying factors that influence the speed of price adjustment after shocks in Vietnam using a multivariate ordered probit model system. We focus on different theories of price stickiness proposed in the literature and the way firms set their prices to justify price adjustment lags. In addition, the variables that representing market, industry and firm characteristics are included in the model to consider their impact on firms' price reaction. Lastly, the paper also examines the asymmetry of price responses to various types of shocks - positive or negative, demand or cost. As claimed by Dias et al. (2015), if there exists the heterogeneity in the speed of firms' responses to shocks, richer and more eclectic macroeconomic models are needed to better understand firms' reactions to different types of shocks and to better predict the effects of monetary policy.

The remainder of this paper is organized as follows. Section 2 briefly describes the survey dataset. Section 3 presents the methodology. Section 4 reports and discusses the main results on the speed of price adjustment. Finally, section 5 concludes. 


\section{The survey data}

In this paper, we extract the data from a survey using questionnaires that were designed in a similar way to those used by Greenslade and Parker (2012) to investigate the speed of price adjustments. The survey was conducted in 2014 with technical support from the General Statistics Office (GSO) and financial support of National Foundation for Science and Technology Development (NAFOSTED) under grant number II 2.3-2012.05. Questionnaires were sent to over 2,000 firms operating in different industries in the three largest cities of the country (Ha Noi in the north, Da Nang in the center and Ho Chi Minh City in the south. The proportion of firms in each city and industry was consistent with what is chosen in the annual national enterprise surveys. To obtain a high response rate, firms were selected randomly from those who had a good record of responding to previous surveys by the GSO. The firms were asked, directly or indirectly through email or phone, about how they set prices. In the end, we obtained a total number of 1,560 complete respondents.

Regarding the speed of price responses, the survey asked firms how long it takes them to adjust their prices following significant demand and cost shocks. In particular, firms were asked the following four questions: (i) "After a significant increase in demand, how much time on average elapses before you raise your prices?"; (ii) "After a significant increase in production costs, how much time on average elapses before you raise your prices?"; (iii) "After a significant decrease in demand, how much time on average elapses before you reduce your prices?"; and (iv) "After a significant decrease in production costs, how much time on average elapses before you reduce your prices?". Given the stress on a significant increase or decrease in demand and costs, these questions imply that the changes are large enough to induce firms sooner or later to adjust their prices. Therefore, the responses to these questions, which will be the dependent variable in our model, are recorded in six categories: 1 - less than one week; 2 - from one week to one month; 3 - from one month to three months; 4 - from three to six months; 5 - from six months to one year and; 6 - more than one year. The distribution of the reaction time is summarized in Table 1.

Table 1: Distribution of the price responses to demand and cost shocks (\%)

\begin{tabular}{clcccc} 
& & \multicolumn{2}{c}{ Demand shocks } & \multicolumn{2}{c}{ Cost shocks } \\
& & Positive & Negative & Positive & Negative \\
\hline 1 & Less than 1 week & 13.2 & 9.2 & 14.7 & 9.8 \\
2 & 1 week to a month & 41.9 & 39.4 & 41.7 & 41.0 \\
3 & 1 to 3 months & 27.2 & 34.4 & 29.0 & 32.1 \\
4 & 3 to 6 months & 7.5 & 10.6 & 8.5 & 8.8 \\
5 & 6 months to 1 year & 4.4 & 3.7 & 2.9 & 4.7 \\
6 & more than 1 year & 5.8 & 2.7 & 3.1 & 3.6 \\
\hline
\end{tabular}




\begin{tabular}{ccccc}
\hline Total & 100 & 100 & 100 & 100 \\
\hline
\end{tabular}

In general, Table 1 shows that firms' reactions to shocks are relatively fast, as over half of the respondents raise or reduce their prices within a month, and over four fifths of them do so within a quarter; these figures are much higher than the corresponding figures in developed countries. For example, in response to either demand or cost shocks, less than half of the firms in the UK (Greenslade and Parker, 2012) and between one and two thirds of the firms in different countries in the Euro area (Fabiani et al., 2006) adjust their prices within a quarter. The results can be attributed to the higher average and more volatile inflation in Vietnam, which causes more frequent wage and price adjustments, as argued by Ball, Mankiw and Romer (1988).

In addition, it also indicates that there is only a little asymmetry in the responses by firms to different types of shocks (demand and cost). However, the asymmetry appears more obviously in the responses of firms to the sign of the shock. For demand shocks, higher demand tends to cause firms to change their prices faster than lower demand. For example, Table 1 illustrates that, within a month, about fifty-five percent of the respondents would have increased their prices when facing a positive demand shock, as compared to forty-eight percent that would have reduced their prices when coping with a negative shock. Similarly, prices also respond more quickly to increasing costs than to decreasing costs. Within a month, nearly fifty-seven percent of the respondents would have increased their prices in reaction to a positive cost shock, while fewer than fifty-one percent of them would have cut their prices in response to a negative one. The results suggest that formal tests should be performed for the hypotheses that there is no difference in the reaction time between demand and cost shocks, and between positive and negative shocks.

To better understand the factors driving price changes, firms are asked to provide the information set and price setting rules used and to give their views on the relevance of various theories or explanations for price rigidity. These theories have been considered important in previous price survey studies or in other empirical or theoretical research. The survey also contains questions on firm characteristics such as firm size, state ownership, destination of main product, market share, competitive intensity, industry, price differentiation, etc. All the information will be used as explanatory variables in our regressions for investigating the speed of price adjustments and their asymmetry in the next section.

\section{Methodology}

In this paper, we use a multivariate ordered probit model system, as described by Ferdous (2010) and Seraj (2012), to study the price responses of firms in Vietnam to four different types of shock, including positive demand, positive cost, negative demand, and negative cost shocks. However, in addition to the factors that are widely recognized in the theory of price stickiness, 
the price-adjustment lag of each firm to each kind of shock is assumed to depend on common unobserved firm's characteristics. These unobserved factors are often measured in terms of a firm-specific random effect. Therefore, a multivariate ordered-response system with random effects will be used to investigate the price adjustments to different types of shock. In this sense, our methodology is more closed to that used by Dias et al. (2015).

The system assumes the presence of an underlying set of multivariate continuous latent variables $\left(y_{i, j}\right)$ whose horizontal partitioning maps into the observed set of ordered outcomes. In this paper, the ordered outcome would be the time interval to which firm $i$ chooses to adjust its price after each type of shock $j$. Such a system allows the use of a general covariance matrix for the underlying latent variables, which translates to a flexible correlation pattern between the observed ordered outcomes.

Let $i$ be an index for firms $(i=1,2, \ldots, I)$, and let $j$ be the index for shock categories $(j$ $=1,2, \ldots, J)$, where $I$ denotes the total number of firms and $J$ denotes the total number of shocks that firms may face (in this study, $I=1560$ and $J=4$ ). Let the number of response values to shock type $j$ be $k j$ (i.e., the discrete levels indexed by $k_{j}$ belong in $\{1,2, \ldots, K j\}$ for shock $j$, where $K=6 \forall j)$. In the ordered response framework notation, the latent propensity $\left(y_{i, j}^{*}\right)$ for each shock category is written as a function of relevant covariates as follows.

$$
y_{i, j}^{*}=\beta_{j}^{\prime} x_{i}+\xi_{j} v_{i}+\varepsilon_{i, j},
$$

where $x_{i}$ is a $(\mathrm{L} \times 1)$ vector of exogenous variables (not including a constant); $\beta_{j}$ is a corresponding $(\mathrm{L} \times 1)$ vector of coefficients to be estimated; $\varepsilon_{i, j}$ is a standard normal error term and; $v_{i}$ is the unobserved firm's characteristics. In the model, $\xi_{j}$ is constrained to be 1 and then $v_{i}$ becomes a random intercept (a random effect) whose impact is shock-specific as different covariates have different coefficients in different equations. Equation (1) becomes a seemingly unrelated regression system formulated in terms of latent variables. However, we estimate the whole system of latent equations taking into account the fact that the response variables (conditionally on the covariates), or $\varepsilon_{i 1}, \varepsilon_{i 2}, \ldots \varepsilon_{i j}$, may be associated. This also help avoid mispecifying the true model with a loss of efficiency.

Since $y_{i, j}^{*}$ is not fully observed but instead we observe $y_{i, j}$ which is related to the observed ordered outcome $y_{i, j}^{*}$ through threshold bounds:

$$
y_{i, j}=k_{j} \quad \text { if } \quad c_{j}^{k-1}<y_{i, j}^{*}<c_{j}^{k},
$$

where $c_{j}^{k}$ is the upper bound threshold for ordered response level $k$ of shock category $j\left(c_{j}^{0}<\right.$ $\left.c_{j}^{1}<\cdots<c_{j}^{K} ; c_{j}^{0}=-\infty, c_{j}^{K}=+\infty \forall j\right)$. To be able to estimate the parameters, we assume that $\varepsilon_{i, j} \mid x_{i}, v_{i} \sim N(0,1)$, where the normalization of the variance to 1 implies no loss of generality. The conditional probability of observing $y_{i, j}=k_{j}$ based on (2) is given by 


$$
\operatorname{Pr}\left(y_{i, j}=k_{j} \mid x_{i}, v_{i}\right)=\operatorname{Pr}\left(c_{j}^{k-1} \leq y_{i, j}^{*}<c_{j}^{k} \mid x_{i}, v_{i}\right) .
$$

Practically, we estimate the system using the generalized structural equation model (gsem) command in STATA. The price-adjustment behavior in response to shocks may vary across regions. To capture this, we robust standard errors with clustering on geographical regions.

\section{Estimation results}

In this section, the estimation results will be presented and discussed. For the ease of interpretation, all the potential explanatory variables for the speed of price reactions are divided into three groups: (i) the information set and the price setting rules firms used in the price reviewing/changing process; (ii) the reasons for that firms do not adjust their prices and; (iii) other control variables regarding market structure and firm/industry characteristics. These independent variables used in the model are dummy variables. Definition and measurement of them are provided in Appendix 1.

There is a concern is that if the degree of multicollinearity is high, the estimates become unstable and the standard errors for the coefficients can get wildly inflated. Therefore, we first examine correlations among independent variables, especially those regarding different sticky price theories, by displaying several measures of collinearity as given in Appendix 2. The values of Variance Inflation Factor (VIF) are far below 10 (The values of tolerance are much greater than 0.1). This implies that there does not exist a linear combination of independent variables, suggesting many of sticky price theories recognized by the Vietnamese firms are possible complements, or at least not mutually exclusive.

The estimation results are presented in Table 2. First, it shows that there are mixed results concerning the information set firms use in price review. Firms applying purely state-dependent rules in the price reviewing process tend to be indifferent in response to either a positive cost or a negative demand shock, but stickier in response to a positive demand shock while faster in reaction to a negative cost shock than firms using time-dependent or mixed time and statedependent rules. Under time-dependence, prices are reviewed at discrete time intervals and independently of the economic conditions as in Taylor (1980) or Calvo (1983). Therefore, in presence of large-enough market shocks, state-dependence normally lead to more flexible prices than time-dependence. However, under time-dependence, the length of intervals may be related to some macroeconomic variables such as inflation average and volatility. For example, Ball, Mankiw and Romer (1988) argued that an increase in the average rate of inflation causes firms to review and adjust prices more frequently to keep up with the rising price level. Therefore, the opposite might be true. In other words, whether state or time-dependence causes firms to adjust their prices faster after shocks will depend critically on not only the size of shocks but also the 
economic conditions. During the time before the survey was carried out, Vietnamese economy had experienced high and volatile inflation. The mean and standard deviation of the year-on-year inflation rate for the period 2008M1-2013M12 were $12.3 \%$ and $7.3 \%$, respectively. As a result, mixed results might occur.

Second, in the price changing process, we find that firms used the rule of thumb tend to adjust their prices more slowly in response to all kind of shocks than their counterparts who based on the market conditions (e.g. the recent past, current or near future market conditions). The result is understandable as firms applying rules of thumb may continue charging prices that are not fully optimal for a longer time even after shocks as explained by Fabiani et al. (2006). Galí and Gertler (1999) and Galí, Gertler and López-Salido (2001) also suggest that stickiness may stem from firms using some form of rule-of-thumb in setting their prices. Therefore, their prices might be more persistent as compared to those of firms that consider a wide range of current and expected information to reset prices. Meanwhile, it seems that the way prices are determined have some important impact on firms' responses. We provide evidence that firms considered the role of principal customer or competitors as "important" or "very important" in their price setting tend to be more flexible in reaction to shocks than those did not. The estimated coefficients regarding principal customer are statistically significant only in equations for positive cost and negative demand shocks, while those related to competitors are statistically significant in all types of shocks. The former result implies that firms are more strongly prompted to change their prices in response to shocks that cause profit losses (rising costs or decreasing demand) than to shocks that lead to profit gains (rising demand or decreasing costs). Meanwhile, the latter suggests that firms whose prices are influenced by competitors may react more quickly to avoid potential coordination failure with their market leaders. Besides, our results show that firms are more reluctant in response to positive demand shocks if their prices are importantly determined by unit cost plus a fixed percentage mark-up and; to negative demand shocks if their prices are primarily regulated by government.

Table 2: Price reactions to shocks by a system of ordered probit models (GSEM method)

\begin{tabular}{|c|c|c|c|c|}
\hline & (1) & (2) & (3) & (4) \\
\hline VARIABLES & $\begin{array}{l}\text { Price response } \\
\text { to positive } \\
\text { demand shocks }\end{array}$ & $\begin{array}{l}\text { Price response } \\
\text { to positive } \\
\text { cost shocks }\end{array}$ & $\begin{array}{l}\text { Price response } \\
\text { to negative } \\
\text { demand shocks }\end{array}$ & $\begin{array}{l}\text { Price response } \\
\text { to negative } \\
\text { cost shocks }\end{array}$ \\
\hline
\end{tabular}

$\begin{array}{lcccc}\text { THE INFORMATION SET AND PRICE SETTING RULES } & & & \\ \text { Purely state-dependent in price review } & 0.282^{* * *} & -0.165 & 0.086 & -0.264 * * * \\ & (0.036) & (0.138) & (0.087) & (0.008) \\ \text { Price is set based on the rule of thumb } & 0.255^{* * *} & 0.276^{* * *} & 0.312^{* * *} & 0.446 * * * \\ & (0.073) & (0.071) & (0.088) & (0.065) \\ \text { Unit cost plus a markup } & 0.328 * * * & 0.221 & 0.043 & -0.092 \\ & (0.084) & (0.168) & (0.238) & (0.290)\end{array}$


Price Adjustment Lags and Their Asymmetries in Vietnam

\begin{tabular}{|c|c|c|c|c|}
\hline VARIABLES & $\begin{array}{c}(1) \\
\text { Price response } \\
\text { to positive } \\
\text { demand shocks } \\
\end{array}$ & $\begin{array}{c}\text { (2) } \\
\text { Price response } \\
\text { to positive } \\
\text { cost shocks }\end{array}$ & $\begin{array}{c}(3) \\
\text { Price response } \\
\text { to negative } \\
\text { demand shocks } \\
\end{array}$ & $\begin{array}{c}\text { (4) } \\
\text { Price response } \\
\text { to negative } \\
\text { cost shocks }\end{array}$ \\
\hline Specified by principal customer & $\begin{array}{c}0.151 \\
(0.111)\end{array}$ & $\begin{array}{c}-0.048 * * * \\
(0.015)\end{array}$ & $\begin{array}{c}-0.168 * * * \\
(0.062)\end{array}$ & $\begin{array}{l}-0.047 \\
(0.109)\end{array}$ \\
\hline Determined by competitors' prices & $-0.493 * * *$ & $-0.286^{* *}$ & $-0.316^{* * *}$ & $-0.378 * * *$ \\
\hline Determined by a regulatory agency & $\begin{array}{c}(0.045) \\
0.003 \\
(0.128)\end{array}$ & $\begin{array}{c}(0.119) \\
-0.043 \\
(0.063)\end{array}$ & $\begin{array}{c}(0.084) \\
0.184 * * * \\
(0.033)\end{array}$ & $\begin{array}{c}(0.053) \\
0.092 \\
(0.079)\end{array}$ \\
\hline \multicolumn{5}{|c|}{ FACTORS/CAUSES OF PRICE RIGIDITY } \\
\hline $\begin{array}{l}\text { The risk that competitors do not change } \\
\text { their prices }\end{array}$ & $\begin{array}{c}0.060 \\
(0.104)\end{array}$ & $\begin{array}{l}-0.091 \\
(0.149)\end{array}$ & $\begin{array}{c}0.124 \\
(0.160)\end{array}$ & $\begin{array}{c}0.080 \\
(0.175)\end{array}$ \\
\hline $\begin{array}{l}\text { The risk that the market price moves in } \\
\text { the opposite direction }\end{array}$ & $\begin{array}{c}0.012 \\
(0.122)\end{array}$ & $\begin{array}{c}0.079 \\
(0.161)\end{array}$ & $\begin{array}{l}-0.182^{*} \\
(0.099)\end{array}$ & $\begin{array}{c}0.031 \\
(0.229)\end{array}$ \\
\hline $\begin{array}{l}\text { The existence of explicit or implicit } \\
\text { contracts }\end{array}$ & $\begin{array}{c}0.073 \\
(0.116)\end{array}$ & $\begin{array}{c}0.127 \\
(0.154)\end{array}$ & $\begin{array}{l}0.228 * * * \\
(0.036)\end{array}$ & $\begin{array}{l}0.174^{*} \\
(0.094)\end{array}$ \\
\hline $\begin{array}{l}\text { The costs related to price changes } \\
\text { (printing, information gathering...) }\end{array}$ & $\begin{array}{l}-0.071 \\
(0.140)\end{array}$ & $\begin{array}{l}-0.091 \\
(0.078)\end{array}$ & $\begin{array}{c}0.273 * * * \\
(0.075)\end{array}$ & $\begin{array}{c}0.242 * * * \\
(0.054)\end{array}$ \\
\hline $\begin{array}{l}\text { The variable costs do not change by } \\
\text { much with market conditions }\end{array}$ & $\begin{array}{c}0.008 \\
(0.093)\end{array}$ & $\begin{array}{c}0.086 \\
(0.162)\end{array}$ & $\begin{array}{l}-0.029 \\
(0.041)\end{array}$ & $\begin{array}{l}-0.027 \\
(0.061)\end{array}$ \\
\hline It would antagonize customers & $\begin{array}{c}0.139 \\
(0.109)\end{array}$ & $\begin{array}{c}0.083 \\
(0.097)\end{array}$ & $\begin{array}{l}-0.060 \\
(0.118)\end{array}$ & $\begin{array}{c}0.254 \\
(0.203)\end{array}$ \\
\hline \multicolumn{5}{|l|}{ CONTROL VARIABLES } \\
\hline Intensity of competition & $\begin{array}{c}0.086 \\
(0.247)\end{array}$ & $\begin{array}{c}-0.367 * * * \\
(0.120)\end{array}$ & $\begin{array}{l}-0.141 \\
(0.195)\end{array}$ & $\begin{array}{c}-0.401 * * \\
(0.193)\end{array}$ \\
\hline Market destination of main product & $\begin{array}{c}0.417 \\
(0.381)\end{array}$ & $\begin{array}{c}0.239 \\
(0.231)\end{array}$ & $\begin{array}{c}0.002 \\
(0.170)\end{array}$ & $\begin{array}{c}0.098 \\
(0.299)\end{array}$ \\
\hline Domestic market share of main product & $\begin{array}{c}0.190 * * \\
(0.096)\end{array}$ & $\begin{array}{c}0.117 \\
(0.126)\end{array}$ & $\begin{array}{c}0.095 * * \\
(0.044)\end{array}$ & $\begin{array}{c}0.086 \\
(0.081)\end{array}$ \\
\hline Firm Size (large firms) & $\begin{array}{l}0.351^{\#} \\
(0.234)\end{array}$ & $\begin{array}{l}0.246^{\#} \\
(0.164)\end{array}$ & $\begin{array}{c}0.220 \\
(0.214)\end{array}$ & $\begin{array}{l}0.243 * \\
(0.129)\end{array}$ \\
\hline Price discrimination by quantity & $\begin{array}{c}-0.459 * * * \\
(0.058)\end{array}$ & $\begin{array}{l}-0.191^{*} \\
(0.100)\end{array}$ & $\begin{array}{c}-0.403 * * * \\
(0.139)\end{array}$ & $\begin{array}{l}-0.081^{*} \\
(0.047)\end{array}$ \\
\hline State ownership (>50\%) & $\begin{array}{c}0.499 * * * \\
(0.051)\end{array}$ & $\begin{array}{c}0.347 * * * \\
(0.092)\end{array}$ & $\begin{array}{l}-0.163 \\
(0.210)\end{array}$ & $\begin{array}{l}0.240 * \\
(0.145)\end{array}$ \\
\hline Trade & $\begin{array}{c}-0.319 * * * \\
(0.123)\end{array}$ & $\begin{array}{l}-0.194^{*} \\
(0.100)\end{array}$ & $\begin{array}{l}0.122^{\#} \\
(0.085)\end{array}$ & $\begin{array}{c}0.280 \\
(0.250)\end{array}$ \\
\hline Manufacturing & $\begin{array}{c}-0.333^{* *} \\
(0.150)\end{array}$ & $\begin{array}{c}-0.278 * * * \\
(0.107)\end{array}$ & $\begin{array}{c}0.125 \\
(0.144)\end{array}$ & $\begin{array}{l}-0.109 \\
(0.078)\end{array}$ \\
\hline Hotel \& Restaurant & $\begin{array}{c}-0.497 * * * \\
(0.112)\end{array}$ & $\begin{array}{l}-0.329^{\#} \\
(0.220)\end{array}$ & $\begin{array}{c}0.017 \\
(0.197)\end{array}$ & $\begin{array}{c}0.266 \\
(0.278)\end{array}$ \\
\hline Transportation & $\begin{array}{c}-0.430 * * * \\
(0.139)\end{array}$ & $\begin{array}{c}-0.481 * * * \\
(0.098)\end{array}$ & $\begin{array}{c}0.070 \\
(0.129)\end{array}$ & $\begin{array}{c}0.028 \\
(0.142)\end{array}$ \\
\hline Construction & $\begin{array}{l}-0.212 \\
(0.452)\end{array}$ & $\begin{array}{l}-0.284 \\
(0.446)\end{array}$ & $\begin{array}{c}0.069 \\
(0.211)\end{array}$ & $\begin{array}{c}0.076 \\
(0.392)\end{array}$ \\
\hline Real estate and renting & $\begin{array}{c}-0.414 * * \\
(0.171)\end{array}$ & $\begin{array}{c}-0.204 * * * \\
(0.075)\end{array}$ & $\begin{array}{c}0.123 \\
(0.086)\end{array}$ & $\begin{array}{c}0.087 \\
(0.225)\end{array}$ \\
\hline
\end{tabular}




\begin{tabular}{|c|c|c|c|c|}
\hline VARIABLES & $\begin{array}{c}(1) \\
\text { Price response } \\
\text { to positive } \\
\text { demand shocks }\end{array}$ & $\begin{array}{c}(2) \\
\text { Price response } \\
\text { to positive } \\
\text { cost shocks } \\
\end{array}$ & $\begin{array}{c}(3) \\
\text { Price response } \\
\text { to negative } \\
\text { demand shocks }\end{array}$ & $\begin{array}{c}\text { (4) } \\
\text { Price response } \\
\text { to negative } \\
\text { cost shocks }\end{array}$ \\
\hline Electricity, Gas \& hot water & $\begin{array}{l}-0.387 \\
(0.812)\end{array}$ & $\begin{array}{l}-0.495 \\
(0.463)\end{array}$ & $\begin{array}{l}0.115 \\
(0.503)\end{array}$ & $\begin{array}{c}0.296 \\
(0.646)\end{array}$ \\
\hline L (Firm' unobserved random effects) & $\begin{array}{l}1.000 \\
(0.000)\end{array}$ & $\begin{array}{c}1.000 \\
(0.000)\end{array}$ & $\begin{array}{c}1.000 \\
(0.000)\end{array}$ & $\begin{array}{c}1.000 \\
(0.000)\end{array}$ \\
\hline $\operatorname{Var}(\mathrm{L})$ & \multicolumn{4}{|c|}{$\begin{array}{c}1.522 * * * \\
(0.265)\end{array}$} \\
\hline \multicolumn{5}{|l|}{ CUT-OFF PARAMETERS } \\
\hline _cut 1 & $\begin{array}{c}-1.925^{* * *} \\
(0.349)\end{array}$ & $\begin{array}{c}-2.224 * * * \\
(0.285)\end{array}$ & $\begin{array}{c}-2.372 * * * \\
(0.516)\end{array}$ & $\begin{array}{c}-2.169 * * * \\
(0.498)\end{array}$ \\
\hline _cut 2 & $\begin{array}{c}0.054 \\
(0.321)\end{array}$ & $\begin{array}{l}-0.247 \\
(0.306)\end{array}$ & $\begin{array}{l}-0.269 \\
(0.339)\end{array}$ & $\begin{array}{c}0.032 \\
(0.314)\end{array}$ \\
\hline _cut 3 & $\begin{array}{c}1.389 * * * \\
(0.288)\end{array}$ & $\begin{array}{c}1.203 * * * \\
(0.381)\end{array}$ & $\begin{array}{c}1.330 * * * \\
(0.247)\end{array}$ & $\begin{array}{c}1.535 * * * \\
(0.195)\end{array}$ \\
\hline _cut 4 & $\begin{array}{c}1.958^{* * *} \\
(0.275)\end{array}$ & $\begin{array}{c}1.967 * * * \\
(0.357)\end{array}$ & $\begin{array}{c}2.290 * * * \\
(0.253)\end{array}$ & $\begin{array}{l}2.231^{* * *} \\
(0.204)\end{array}$ \\
\hline _cut 5 & $\begin{array}{c}2.405 * * * \\
(0.259)\end{array}$ & $\begin{array}{c}2.391 * * * \\
(0.434)\end{array}$ & $\begin{array}{c}2.973 * * * \\
(0.255)\end{array}$ & $\begin{array}{c}2.852 * * * \\
(0.268)\end{array}$ \\
\hline $\begin{array}{l}\text { TEST } \\
\text { Log pseudolikelihood }\end{array}$ & & -773 & 604 & \\
\hline Observations & 1,560 & 1,560 & 1,560 & 1,560 \\
\hline
\end{tabular}

Note: Robust standard errors with clustering on geographical region in parentheses, and $* * *$ marks significance at $1 \%$ level, ** marks significance at $5 \%$ level, * marks significance at $10 \%$ level, and ${ }^{\#}$ marks significance at $12 \%$ level. The sector of agriculture, forestry \& fishery as a reference base for industry dummies.

There could be many reasons why firms do not change their prices in response to every change in supply and demand. It may be because of the costs associated with gathering information and reprinting price lists (menu costs), or because firms do not want to trigger a price war with competitors (coordination failure), or because firms have an official or unofficial agreement with their customers to supply a certain product at a specific price (explicit and implicit contracts), or because firms want to build up long-term customer relationships and to try to avoid antagonizing customers (customer relations). In the survey, firms were asked to assess how important these factors are in deciding not to change their prices. We find that those firms considering menu costs and implicit and explicit contracts important or very important display a slower adjustment after shocks. However, the estimated coefficients are only statistically significant in case of negative demand and cost shocks. That means menu costs are more likely to prevent firms from cutting rather than raising prices. Similarly, contracts are more likely to be negotiated with conditions in favor of firms allowing them to delay reducing prices in response to negative demand and cost shocks. In other words, the impact of menu costs and contracts on 
the price reaction of Vietnamese firms depends on the direction of shocks. They seem to induce firms to respond more slowly only to shocks that drive prices downwards, rather than to shocks that move prices upwards. The results are different from the findings by Dias et al. (2015) that menu costs matter for the speed of price adjustment only in case of demand shocks and that contracts cannot explain differences in the price adjustment lags across firms.

Regarding the influence of other factors on the speed of price adjustment, we also find an asymmetrical pattern of prices. In particular, we find that firms operating in markets with a high or medium level of competition tend to be quicker to react to cost shocks than to demand shocks. It is possible that in a competitive environment, price changes due to cost (demand) changes can be viewed by customers as fair (unfair) and firms are more likely to increase their prices in response to cost shocks than to demand shocks as they try to avoid antogonism from customers (Okun, 1981). Meanwhile, firms with a market share of the main product over $5 \%$ tend to react more slowly to demand shocks. The evidence is somewhat consistent with the finding by Álvarez and Hernando (2005) that larger firms have a higher probability of price adjustment after demand shocks.

In addition, in the survey, the majority of the respondents said that they apply some kind of price differentiation, with around two fifths of them doing so according to the quantity sold and over half of them deciding case by case. Our results indicate that firms doing quantity discounts are more flexible in reaction to all kind of shocks. A similar conclusion is also found by Dias et al. (2015). Furthermore, the speed of price response to shocks also varies with different proportions of state ownership and firm sizes. Firms that are dominantly state owned (over 50\%) or employs more than 50 workers (large size) tend to be slower at adjusting their prices than private or medium and small firms. We do not find any evidence that market destination has a significant impact on price stickiness. Finally, we also find differences in the speed of reaction between industries. Firms that operate in service (trade, hotel and restaurant, transportation, real estate and renting) or industry (manufacturing) sectors adjust their prices more rapidly in response to shocks than those in agriculture, forestry and fishery (the base) sector. However, the estimated coefficients are only statistically significant in case of positive shocks. That means firms in these sectors are more prompted to increase than to decrease their prices.

Table 1 and 2 indicates that firms may response differently to different types of shocks. Following Dias et al. (2015), we formally investigate the differences by testing the above unrestricted model (Table 2) against restricted models imposing symmetry that the parameters in the equations for different types of shocks are identical. In particular, we examine (i) the difference in the reaction to positive and negative demand shocks; (ii) the difference in the reaction to positive and negative cost shocks; (iii) the difference in reaction to positive demand 
and positive cost shocks and; (iv) the difference in reaction to negative demand and negative cost shocks. A wald test is implemented in each case to check if there is a significant difference between the shock-specific parameters in different equations.

The results of the four tests displayed in Table 3 show that the null hypothesis of symmetry within either demand or cost shocks can not be rejected at any traditional sinificance level. Meanwhile, the null hypothesis of symmetry between positive demand and cost shocks is rejected at the significance level of $10 \%$, and between negative demand and cost shocks is rejected at the significance level of $1 \%$, implying that firms respond differently to demand and cost shocks. In other words, firms may react differently to shocks that cause profit losses and to shocks that lead to profit gains. The evidence is in line with that found by Fabiani et al. (2006) and Dias et al. (2015).

Table 3: Tests of symmetry in price response to the types of shocks

\begin{tabular}{|c|c|}
\hline \multicolumn{2}{|c|}{ Symmetry within shocks } \\
\hline $\begin{array}{l}\text { Positive and negative demand shocks } \\
\text { chi } 2(2)=1.85 \\
\text { Prob }>\text { chi } 2=0.3967\end{array}$ & $\begin{array}{l}\text { Positive and negative cost shocks } \\
\text { chi } 2(2)=1.06 \\
\text { Prob }>\text { chi } 2=0.5889\end{array}$ \\
\hline \multicolumn{2}{|c|}{ Symmetry between shocks } \\
\hline $\begin{array}{l}\text { Positive demand and cost shocks } \\
\text { chi2(2) }=5.66 \\
\text { Prob > chi } 2=0.0591\end{array}$ & $\begin{array}{l}\text { Negative demand and cost shocks } \\
\text { chi2 }(2)=53.28 \\
\text { Prob }>\text { chi } 2=0.0000\end{array}$ \\
\hline
\end{tabular}

Note: chi2(2) stands for the Wald test statistic, and Prob for the corresponding P-value.

\section{Conclusions}

This paper uses a multivariate ordered probit model system to study the price responses of Vietnamese firms to four different types of shock, including positive demand, positive cost, negative demand, and negative cost shocks. The response of each firm to each kind of shock is assumed to depend on common unobserved firm's characteristics, which are measured in terms of a firm-specific random effect. The results first indicate that whether state or time-dependence causes firms to adjust their prices faster after shocks may depend critically on not only the size of shocks but also the economic conditions. The mixed results are attributable to persistently high inflation of Vietnamese economy during the time before the survey.

Second, we provide evidence that firms used the rule of thumb in price setting tend to adjust their prices more slowly in response to all kind of shocks than their counterparts who based on the market conditions. This is understandable as firms applying rules of thumb may 
continue charging prices that are not fully optimal for a longer time even after shocks. Therefore, their prices might be more persistent as compared to those of firms that consider a wide range of current and expected information to reset prices. Furthermore, we find evidence that firms considered principal customer as "important" or "very important" in their price setting are more likely to react to shocks that cause profit losses (rising costs or decreasing demand) than to shocks that lead to profit gains (rising demand or decreasing costs). Meanwhile, firms whose prices are influenced by competitors are discovered to be quicker in response to all type of shocks to avoid potential coordination failure with their market leaders.

In addition, we find evidence that menu costs and implicit and explicit contracts with customers are considered as the two most relevant explanations for rigid prices. However, the impact of menu costs and contracts on the price reaction of Vietnamese firms depends on the direction of shocks. They seem to induce firms to respond more slowly only to shocks that drive prices downwards, rather than to shocks that move prices upwards. Furthermore, concerning other factors that influence the speed of price adjustment, we also find an asymmetrical pattern of prices. We find that the degree of competition is positively associated with a faster response to cost shocks, and that the level of market share is positively correlated to a slower reaction to demand shocks. Besides, the practicing of quantity discounts, the proportion of state ownership and the size of firms tend to induce firms to react more slowly to almost all types of shocks. We also find that the speed of price adjustment varies significantly with the sector where firms operate. Firms that belong to manufacturing and service sectors seem to respond faster to positive shocks than those in agriculture, forestry and fishery sector.

Finally, we provide evidence that firms adjust prices asymmetrically in response to shocks, depending on the source of the shock. In more detail, prices react differently between demand and cost shocks of the same direction.

\section{REFERENCES}

Álvarez, L. J. and Hernando, I. (2005). The Price Setting Behaviour of Spanish Firms: Evidence from Survey Data, ECB Working Paper, No. 538.

Álvarez, L. J., Burriel, P. and Hernando, I. (2010). Price-setting Behaviour in Spain: Evidence from micro PPI data. Managerial and Decision Economics, vol. 31(2/3): 105-121.

Amirault, D., Kwan, C. and Wilkinson, G. (2004). A survey of the price-setting behavior of Canadian companies. Bank of Canada Review, Winter 2004-05: 29-40. 
Apel M., Friberg R., and Hallsten K. (2005). Microfoundations of Macroeconomic Price Adjustment: Survey Evidence from Swedish Firms. Journal of Money, Credit and Banking, Blackwell Publishing, vol. 37(2): 313-38

Ball, L., Mankiw, N. G. and Romer, D. (1988). The New Keynesian Economics and the Output-Inflation Trade-Off. Brookings Papers on Economic Activity, vol. 1: 1-82.

Blinder, A. S. (1991). Why are prices sticky? Preliminary results from an interview study. American Economic Review, 81(2): 89-96.

Blinder, A. S. (1994). On Sticky Prices: Academic Theories Meet the Real World, In Monetary Policy, ed. N. G. Mankiw. Chicago and London: University of Chicago Press.

Blinder, A. S., Canetti E., Lebow D. E., and Rudd J. B. (1998). Asking About Prices: A New Approach to Understanding Price Stickiness. New York: Russell Sage Foundation.

Calvo, Guillermo A. (1983). Staggered Prices in a Utility-Maximizing Framework. Journal of Monetary Economics, vol. 12(3): 383-98.

Dias, D. A., Marques, C. R., Martins, F. and Silva, S. J. M. C. (2015). Understanding Price Stickiness: Firm-level Evidence on Price Adjustment Lags and Their Asymmetries. Oxford Bulletin of Economics and Statistics, vol. 77(5): 701-718.

Fabiani S., Druant M., Hernando I., Kwapil C., Landau B., Loupias C., Martins F., Mathä T., Sabbatini R., Stahl H., and Stokman A. (2006). What Firms' Surveys Tell Us about Price-Setting Behavior in the Euro Area. International Journal of Central Banking, vol. 2(3): 3-47.

Ferdous, N., Eluru, N. Bhat, C. R. and Meloni, I. (2010). A multivariate ordered-response model system for adults' weekday activity episode generation by activity purpose and social context. Transportation Research Part B: Methodological, vol. 44(8-9): 922-943.

Galí, J. and M. Gertler. (1999). Inflation dynamics: a structural econometric analysis. Journal of Monetary Economics, vol. 44(2): 195-222.

Galí, J., M. Gertler and D. López-Salido. (2001). European inflation dynamics. European Economic Review, vol. 45: 1237-1270.

Greenslade J. and Parker M. (2012). New insights into price-setting behaviour in the UK: introduction and survey results. Economic Journal, vol. 122(558): 1-15.

Hall S., Walsh M., and Yates A. (2000). Are UK Companies' Prices Sticky? Oxford Economic Papers, 52(3): 425-446.

Munnik, De D., and Kuan Xu. (2007). Microfoundations of Price-Setting Behavior: Evidence from Canadian Firms. Bank of Canada Working Paper no. 31. Ottawa: Bank of Canada.

Nakagawa S., Hattori R., and Takagawa I. (2000). Price-Setting Behavior of Japanese Companies - The Results of "Survey of Price-Setting Behavior of Japanese Companies" and Its Analysis. Bank of Japan, Research and Statistics Department. 
Price Adjustment Lags and Their Asymmetries in Vietnam

Okun, A. (1981). Prices and Quantities: A Macroeconomic Analysis. The Brookings Institution, Washington D.C.

Park A., Rayner V. and D'Arcy P. (2010). Price-setting Behaviour - Insights from Australian Firms. Australian Central Bank Bulletin, June Quarter 2010.

Seraj, S, Sidharthan R., Chandra B., Pendyala, R. and Goulias, K. (2012). Parental Attitudes

Toward Children Walking and Bicycling to School: Multivariate Ordered Response Analysis. Transportation Research Record: Journal of the Transportation Research Board, vol. 2323: 4655.

Taylor, John B. (1980). Aggregate Dynamics and Staggered Contracts. Journal of Political Economy, vol. 88(1): 1-23.

\section{Acknowledgments}

This research is funded by Vietnam National Foundation for Science and Technology Development (NAFOSTED) under grant number II 2.3-2012.05.

\section{APPENDIX 1: DEFINITION AND MEASUREMENT OF VARIABLES}

\begin{tabular}{|c|c|c|}
\hline Code & Variables & Definition and measurement \\
\hline \multicolumn{3}{|c|}{ DEPENDENT VARIABLES: PRICE RESPONSES TO FOUR TYPES OF SHOCK } \\
\hline y1 & $\begin{array}{l}\text { Price response to a } \\
\text { positive demand shock }\end{array}$ & \\
\hline y2 & $\begin{array}{l}\text { Price response to a } \\
\text { positive cost shock }\end{array}$ & $\begin{array}{l}\text { Ordered response variable: } 1=\text { less than one week; } 2=\text { from one week to } \\
\text { one month; } 3=\text { from one to three months; } 4=\text { from three to six months; }\end{array}$ \\
\hline y3 & $\begin{array}{l}\text { Price response to a } \\
\text { negative demand shock }\end{array}$ & $5=$ from six months to one year; $6=$ more than one year. \\
\hline y4 & $\begin{array}{l}\text { Price response to a } \\
\text { negative cost shock }\end{array}$ & \\
\hline \multicolumn{3}{|c|}{ PRICE SETTING RULES } \\
\hline preview & $\begin{array}{l}\text { Purely state-dependent in } \\
\text { price review (In response } \\
\text { to specific events) }\end{array}$ & $\begin{array}{l}\text { dummy equals } 1 \text { if the firm generally reviews the domestic price of its } \\
\text { main product in response to specific events (e.g., a substantial increase in } \\
\text { input costs), otherwise equals } 0 \text {. }\end{array}$ \\
\hline pbase_rthumb & $\begin{array}{l}\text { Price is set based on the } \\
\text { rule of thumb }\end{array}$ & $\begin{array}{l}\text { dummy equals } 1 \text { if the firm sets the domestic price of its main product } \\
\text { based on the rule of thumb, otherwise equals } 0 .\end{array}$ \\
\hline pset_markup & Unit cost plus a markup & $\begin{array}{l}\text { dummy equals } 1 \text { if the firm considers that 'the markup pricing' as an } \\
\text { important or very important factor for setting its price, otherwise equals } \\
0 .\end{array}$ \\
\hline pset_customer & $\begin{array}{l}\text { Specified by principal } \\
\text { customer }\end{array}$ & $\begin{array}{l}\text { dummy equals } 1 \text { if the firm considers that 'the principal customer' as an } \\
\text { important or very important factor for setting its price, otherwise equals } \\
0 \text {. }\end{array}$ \\
\hline pset_compet & $\begin{array}{l}\text { Determined by } \\
\text { competitors' price }\end{array}$ & $\begin{array}{l}\text { dummy equals } 1 \text { if the firm considers that 'the competitors' price' as an } \\
\text { important or very important factor for setting its price, otherwise equals }\end{array}$ \\
\hline
\end{tabular}




\begin{tabular}{|c|c|c|}
\hline Code & Variables & Definition and measurement \\
\hline pset_legal & $\begin{array}{l}\text { Determined by a } \\
\text { regulatory agency }\end{array}$ & $\begin{array}{l}0 . \\
\text { dummy equals } 1 \text { if the firm considers that 'the regulatory agency' as an } \\
\text { important or very important factor for setting its price, otherwise equals } \\
0 .\end{array}$ \\
\hline \multicolumn{3}{|c|}{ FACTORS/CAUSES OF PRICE RIGIDITY } \\
\hline pstick1 & $\begin{array}{l}\text { The risk that competitors } \\
\text { do not change their } \\
\text { prices }\end{array}$ & $\begin{array}{l}\text { dummy equals } 1 \text { if the firm considers the risk that competitors do not } \\
\text { change their prices as an important or very important factor for } \\
\text { postponing price changes or just changing slightly their prices, otherwise } \\
\text { equals } 0 .\end{array}$ \\
\hline pstick2 & $\begin{array}{l}\text { The risk that the market } \\
\text { price moves in the } \\
\text { opposite direction }\end{array}$ & $\begin{array}{l}\text { dummy equals } 1 \text { if the firm considers the risk that the market price } \\
\text { moves in the opposite direction as an important or very important factor } \\
\text { for postponing price changes or just changing slightly their prices, } \\
\text { otherwise equals } 0 \text {. }\end{array}$ \\
\hline pstick3 & $\begin{array}{l}\text { The existence of explicit } \\
\text { or implicit contracts }\end{array}$ & $\begin{array}{l}\text { dummy equals } 1 \text { if the firm considers the existence of explicit or implicit } \\
\text { contracts as an important or very important factor for postponing price } \\
\text { changes or just changing slightly their prices, otherwise equals } 0 \text {. }\end{array}$ \\
\hline pstick4 & $\begin{array}{l}\text { The costs related to price } \\
\text { changes }\end{array}$ & $\begin{array}{l}\text { dummy equals } 1 \text { if the firm considers the costs related to price changes } \\
\text { (e.g., printing, information gathering, etc.) as an important or very } \\
\text { important factor for postponing price changes or just changing slightly } \\
\text { their prices, otherwise equals } 0 \text {. }\end{array}$ \\
\hline pstick5 & $\begin{array}{l}\text { The variable costs do not } \\
\text { change by much with } \\
\text { market conditions }\end{array}$ & $\begin{array}{l}\text { dummy equals } 1 \text { if the firm considers the variable costs do not change by } \\
\text { much with market conditions as an important or very important factor for } \\
\text { postponing price changes or just changing slightly their prices, otherwise } \\
\text { equals } 0 \text {. }\end{array}$ \\
\hline pstick6 & $\begin{array}{l}\text { It would antagonize } \\
\text { customers }\end{array}$ & $\begin{array}{l}\text { dummy equals } 1 \text { if the firm considers it would antagonize customers as } \\
\text { an important or very important factor for postponing price changes or } \\
\text { just changing slightly their prices, otherwise equals } 0 \text {. }\end{array}$ \\
\hline \multicolumn{3}{|c|}{ OTHER CONTROL VARIABLES } \\
\hline competitive & Intensity of competition & $\begin{array}{l}\text { dummy equals } 1 \text { if the intensity of competition for the main product is } \\
\text { ranked by the firm as a medium or high intensity of competition, } \\
\text { otherwise equals } 0 \text {. }\end{array}$ \\
\hline pdest1 & $\begin{array}{l}\text { Market destination of } \\
\text { main product }\end{array}$ & $\begin{array}{l}\text { dummy equals } 1 \text { if the firm does not consider Vietnam market as the } \\
\text { principal market for its main product, otherwise equals } 0 .\end{array}$ \\
\hline mshare & $\begin{array}{l}\text { Domestic market share } \\
\text { of main product }\end{array}$ & $\begin{array}{l}\text { dummy equals } 1 \text { if the market share of main product is greater than } 5 \% \text {, } \\
\text { otherwise equals } 0 \text {. }\end{array}$ \\
\hline firm_size1 & Firm Size & $\begin{array}{l}\text { dummy equals } 1 \text { if the labor size of firm greater than } 50 \text { employees, } \\
\text { otherwise equals } 0 .\end{array}$ \\
\hline pdisc & $\begin{array}{l}\text { Price discrimination by } \\
\text { quantity }\end{array}$ & $\begin{array}{l}\text { dummy equals } 1 \text { if the price of main product is decided dependent on the } \\
\text { quantity sold, otherwise equals } 0 .\end{array}$ \\
\hline state_owned & State ownership & $\begin{array}{l}\text { dummy equals } 1 \text { if the proportion of state ownership greater than } 50 \% \text {, } \\
\text { otherwise equals } 0 \text {. }\end{array}$ \\
\hline trade & Trade & $\begin{array}{l}\text { dummy equals } 1 \text { if the firm operates in trade industry, otherwise equals } \\
0 .\end{array}$ \\
\hline manufacturing & Manufacturing & $\begin{array}{l}\text { dummy equals } 1 \text { if the firm operates in manufacturing industry, } \\
\text { otherwise equals } 0 .\end{array}$ \\
\hline hotels_restaurants & Hotel \& Restaurant & $\begin{array}{l}\text { dummy equals } 1 \text { if the firm operates in hotels and restaurants, otherwise } \\
\text { equals } 0 .\end{array}$ \\
\hline transport & Transportation & $\begin{array}{l}\text { dummy equals } 1 \text { if the firm operates in transportation industry, } \\
\text { otherwise equals } 0 \text {. }\end{array}$ \\
\hline electricity & $\begin{array}{l}\text { Electricity, gas \& hot } \\
\text { water }\end{array}$ & $\begin{array}{l}\text { dummy equals } 1 \text { if the firm operates in electricity, gas \& hot water, } \\
\text { otherwise equals } 0 .\end{array}$ \\
\hline
\end{tabular}


Price Adjustment Lags and Their Asymmetries in Vietnam

\begin{tabular}{l|l|l}
\hline Code & Variables & Definition and measurement \\
\hline construction & Construction & $\begin{array}{l}\text { dummy equals } 1 \text { if the firm operates in construction industry, otherwise } \\
\text { equals } 0 .\end{array}$ \\
realestate & Real estate and renting & $\begin{array}{l}\text { dummy equals } 1 \text { if the firm operates in real estate and renting industry, } \\
\text { otherwise equals } 0 .\end{array}$ \\
\hline
\end{tabular}

\section{APPENDIX 2: COLLINEARITY DIAGNOSTICS}

\begin{tabular}{|c|c|c|c|c|}
\hline Variable & VIF & SQRT VIF & Tolerance & R-Squared \\
\hline preview & 1.03 & 1.02 & 0.968 & 0.032 \\
\hline pbase_rthumb & 1.10 & 1.05 & 0.905 & 0.095 \\
\hline pset_markup & 1.17 & 1.08 & 0.853 & 0.147 \\
\hline pset_customer & 1.22 & 1.11 & 0.818 & 0.182 \\
\hline pset_compet & 1.17 & 1.08 & 0.856 & 0.144 \\
\hline pset_legal & 1.13 & 1.06 & 0.887 & 0.113 \\
\hline pstick1 & 1.31 & 1.15 & 0.763 & 0.237 \\
\hline pstick2 & 1.35 & 1.16 & 0.738 & 0.262 \\
\hline pstick3 & 1.17 & 1.08 & 0.857 & 0.143 \\
\hline pstick4 & 1.28 & 1.13 & 0.784 & 0.216 \\
\hline pstick5 & 1.23 & 1.11 & 0.813 & 0.187 \\
\hline pstick6 & 1.22 & 1.10 & 0.821 & 0.180 \\
\hline competitive & 1.07 & 1.04 & 0.930 & 0.070 \\
\hline pdest1 & 1.10 & 1.05 & 0.909 & 0.091 \\
\hline mshare & 1.10 & 1.05 & 0.912 & 0.088 \\
\hline firm_size1 & 1.19 & 1.09 & 0.837 & 0.163 \\
\hline pdisc & 1.11 & 1.05 & 0.904 & 0.097 \\
\hline state_owned & 1.11 & 1.05 & 0.899 & 0.101 \\
\hline Trade & 5.05 & 2.25 & 0.198 & 0.802 \\
\hline Manufacturing & 4.59 & 2.14 & 0.218 & 0.782 \\
\hline Hotels_restaurants & 3.73 & 1.93 & 0.268 & 0.732 \\
\hline Transport & 3.20 & 1.79 & 0.312 & 0.688 \\
\hline Construction & 2.65 & 1.63 & 0.378 & 0.622 \\
\hline Realestate & 1.65 & 1.28 & 0.606 & 0.394 \\
\hline Electricity & 1.29 & 1.14 & 0.774 & 0.226 \\
\hline Mean VIF & 1.73 & \multicolumn{2}{|c|}{ Condition Number } & 8.821 \\
\hline
\end{tabular}

These results are produced by using the collin command in STATA written by Philip Ender at University of California, Los Angeles (UCLA). 
Price Adjustment Lags and Their Asymmetries in Vietnam 